\title{
Epidemiologie in de contramine
}

Citation for published version (APA):

Knipschild, P. (1985). Epidemiologie in de contramine. Maastricht University. https://doi.org/10.26481/spe.19851122ps

Document status and date:

Published: 22/11/1985

DOI:

10.26481/spe.19851122ps

Document Version:

Publisher's PDF, also known as Version of record

\section{Please check the document version of this publication:}

- A submitted manuscript is the version of the article upon submission and before peer-review. There can be important differences between the submitted version and the official published version of record.

People interested in the research are advised to contact the author for the final version of the publication, or visit the DOI to the publisher's website.

- The final author version and the galley proof are versions of the publication after peer review.

- The final published version features the final layout of the paper including the volume, issue and page numbers.

Link to publication

\footnotetext{
General rights rights.

- You may freely distribute the URL identifying the publication in the public portal. please follow below link for the End User Agreement:

www.umlib.nl/taverne-license

Take down policy

If you believe that this document breaches copyright please contact us at:

repository@maastrichtuniversity.nl

providing details and we will investigate your claim.
}

Copyright and moral rights for the publications made accessible in the public portal are retained by the authors and/or other copyright owners and it is a condition of accessing publications that users recognise and abide by the legal requirements associated with these

- Users may download and print one copy of any publication from the public portal for the purpose of private study or research.

- You may not further distribute the material or use it for any profit-making activity or commercial gain

If the publication is distributed under the terms of Article $25 \mathrm{fa}$ of the Dutch Copyright Act, indicated by the "Taverne" license above, 


\section{EPIDEMIOLOGIE IN DE CONTRAMINE}

Rede uitgesproken bilj de aanvaarding van het ambt van gewoon hoogleraar in de epidemiologie aan de Rijksuniversiteit Limburg op 22 november 1985 
Zel ea drukwerk E8U Massuicht 1985 
Mijnheer de rector,

Geachte aanwezigen,

De gezondheidszorg in een land als Nederland is van hoge kwaliteit. Dat heeft te maken met de kennis die wij van allerlei ziektes verworven hebben: door ervaringen in de praktijk, door observaties in het laboratorium en door metingen in het veld. Maar er zijn ook nog veel lacunes. Dus wordt uit alle macht geprobeerd onze kennis van ziektes te vergroten. Dat gaat erg moeizaam en misschien komt dat mede omdat we te veel voortborduren op wat we al denken te weten. Het loont óók de moeite om de bestaande kennis ter discussie te stellen. Eén manier om dat te doen is in de contramine gaan. Naarmate iets stelliger beweerd wordt, probeert $U$ uit, in hoeverre het tegenovergestelde standpunt te verdedigen valt. De epidemiologie kan daarbij helpen. U zult verbaasd zijn, hoe weinig bepaalde beweringen voorstellen. Sommige kennis kan beter verdwijnen, er blijft dan nog genoeg over. En van daaruit kan nieuwe kennis over ziektes veel eenvoudiger ontwikkeld worden.

Wat is kenmerkend voor de epidemiologie? Meer dan in andere disciplines pretenderen epidemiologen iets over het ontstaan, de diagnostiek en de prognose van ziektes te weten te komen op basis van het vóórkomen van ziektes bij groepen mensen.

Centraal staat de kennis van het vóorkomen, de zogenaamde beschrljuende epidemiologle. Hierbij gaat het om meer dan thet beschrijven van epidemieën van besmettelijke ziektes. De meeste epidemiologen in Nederlañd hebben daar nauwelijks belangstelling voor. Tegenwoordig ligt de nadruk veel meer op andere ziektes, zoals kanker of hart-en vaatziektes.

Het louter beschrijven van het vóórkomen van allerlei aandoeningen is een weinig inspirerende bezigheid. Het wordt vaak pas interessant, als aldus inzichten worden verkregen in bijvoorbeeld het ontstaan van zlektes. Welke factoren bepalen het nieuw vóórkomen van ziektes? Deze factoren worden risicofactoren of etiologische factoren genoemd, maar U mag ook gewoon van oorzaken spreken. Het deel van de epidemiologie dat over oorzaken van ziektes gaat, wordt well etlologische epidemiologie genoemd.

Daarnaast is er in de epidemiologie steeds meer aandacht voor de diagnostiek. Het gaat er dan bijvoorbeeld om, in hoeverre bepaalde klachten en symptomen aanwijzingen geven over het vóórkomen van ziektes. Het deel van de epidemiologie dat zich met diagnostische factoren bezig houdt, kan diagnostische epidemlologle genoemd worden. 
Het wóorkomen van ziektes wordt niet alleen bepaald door het ontstaan, maar ook door het beloop van ziektes. Hierbij spelen al evenzeer allerlei factoren een rol, de zogenaamde prognostische factoren. Het deel van de epidemiologie dat zich vooral hierop richt, heet dus prognostische epidemiologle. De diagnostische en prognostische epidemiologie samen worden wel klinische epidemiologie genoemd.

In mijn inaugurele rede zal ik niet ingaan op de beschrijvende epidemiologie. Over de etiologische, diagnostische en prognostische epidemiologie gaik U des te meer vertellen. Om er geen droog betoog van te maken, zal ik nogal eens gebruik maken van voorbeelden.

De voorbeelden zijn niet willekeurig gekozen, maar vanuit de contramine. Naar mijn overtuiging worden in de gezondheldszorg nogal eens dingen beweerd, enkel op basis van de indrukken van de een of andere autoriteit. Als doorgevraagd wordt naar de achtergrond van bepaalde beweringen, volgt meestal een uitleg van het onderliggende mechanisme. Er wordt teruggevallen op bepaalde kennis die door de zogenaamde basisvakken geleverd is. Dat is een correcte benadering, maar ze is niet voldoende. Waar mogelijk, dienen beweringen over het ontstaan, de diagnostiek en de prognose van ziektes bij de mens ook met epidemiologisch onderzoek bevestigd en nader gekwantificeerd te worden. Met mijn voorbeelden hoop ik aan te geven dat allerlei veronderstelde zekerheden best nog eens door een epidemiologische bril mogen worden bekeken. De voorbeelden geven bovendien aanleiding om af en toe een mening te geven over wat er met de bestaande kennis gebeurt en dient te gebeuren. 


\section{ONTSTAAN}

Achtereenvolgens zal worden ingegaan op de rol die de epidemiologie kan spelen bij de kennis van het ontstaan, de diagnostiek en de prognose van allerlei ziektes.

Allereerst gaat het dus over het ontstaan van ziektes. In westerse landen zoals Nederland overlijdt de meerderheid van de bevolking aan kanker of éen van de hart-en vaatziektes. Het is begrijpelijk dat in het wetenschappelijk onderzoek veel aandacht is besteed aan het ontstaan. In etiologische epidemiologie is bij voortduring de vraag gesteld: welke factoren bepalen het nieuw vóórkomen van deze zlektes?

Globaal zijin er twee manieren om meer hierover te weten te komen: een grave en een fijne manier. De grove manier gaat uit van de beschrijvende epidemiologie. Men constateert dat er grote verschillen zijn in het vóorkomen van bepaalde ziektes, bijvoorbeeld tussen vroeger en nu of tussen het ene gebied en het andere. Vervolgens probeert men deze verschillen te verklaren uit verschillen in het vóörkomen van veronderstelde oorzaken. In het algemeen leidt dergelijk onderzoek tot niets. Bijna steeds ontstaat er discussie over de keuze van de bestudeerde oorzaken en ook de interpretatie is vaak nogal willekeurig. Ik vind daarom dat dergelijke studies het predikaat: etiologische epidemiologie niet of nauwelijks verdienen.

Laat ik een woorbeeld geven. Uit de beschrijvende epidemiologie is gebleken dat maagkanker in Nederland nu minder voorkomt dan vroeger. We weten niet waarom. En dan is het al te gemakkelijk om te stellen dat er in Nederland steeds meer ijskasten zijn gekomen en dat het dus daardoor komt. We zijn ook steeds meer "uit de muur" gaan eten en met net zo veel recht kan beweerd worden dat dát beschermt tegen maagkanker. Wat voor verschillen in de tijj geldt, geldt ook voor verschillen tussen gebieden. In Zuid-Limburg komt maagkanker meer voor dan in bijwoorbeeld Amsterdam. Dus zijn er mensen die beweren dat dat komt door de mijnen. Met net zo veel recht kan beweerd worden dat het eten van vlaai de kans op maagkanker verhoogt.

Intussen komen op deze manier wel de praatjes in de wereld. Langzamer hand zijn er zoveel beweringen over oorzaken van met name kanker en hart-en vaatziektes dat geen mens er meer wijs uit wordt. De ene boude bewering heeft nog imaar net de krant gehaald, of de televisie zendt al weer een volgende uit. Men lijkt maar weinig moeite te heb ben om dapper allerlei oorzaken aan te geven, vaak met bijbehorende adviezen. Soms krijg ik de indruk dat vooral die gewoontes het moeten ontgelden die vanuit een puriteins milieu bij voorbaat al verwerpelijk worden geacht. 
Wil men een epidemiologisch onderzoek doen naar een ziekteoorzaak, dan is een veel fijnere methodiek nodig. Een minimumvoorwaarde hierbij is dat de eventuele aanwezigheid van zowel de oorzaak als de ziekte voor iedere deelnemer aan het onderzoek afzonderlijk wordt bepaald. Er zijn nog veel meer voorwaarden, maar bespreking daarvan zou te veel tijd vergen.

Vaak wordt in etiologisch epidemiologisch onderzoek gebruik gemaakt van een zogenaamde patient-controle benadering. Men begint dan met een groep patiènten met de ziekte en meet hierin het woórkomen van de oorzaak. Hetzelfde doet men in een controlegroep zonder de zlekte. Als er sprake is van een echte ziekteoorzaak, zal het vórkomen hiervan groter zijn in de groep patiënten dan in de controlegroep.

Voor een voorbeeld van het laatste keren we nog eens terug naar de bewering dat het verhoogd wóórkomen van maagkanker in Zuid-Limburg door de mijnen komt. Artsen die veel te maken hebben met maagkankerpatiënten, zullen geneigd zijn deze bewering te bevestigen. Ze hebben zeker wel eens een ex-mijnwerker onder hun patiënten gehad. Maar dat zegt nog weinig. In epidemiologisch onderzoek gaat het erom, hoe vaak dat voorkomt. Gerard Swaen, geen ex-mijnwerker, maar wel een ex-medewerker van onze capaciteitsgroep, heeft dat onlangs uitgezocht. In drie ziekenhuizen in Zuid-Limburg trof hij ruim 300 mannen met maagkanker aan en van dezen bleek maar liefst éen ap de viff in de mijnen gewerkt te hebben. Dat is erg veel, maar hoeveel? Als in de mijnen werken de kans op maagkanker verhoogt, zal men onder maagkankerpatiënten extra veel mijnwerkers aantreffen. Vraag is dus, of onder oudere mannen zonder maagkanker veel minder ex-mijnwerkers vóorkomen. En dat blijkt niet het gevall te zijn. Ook van dezen heeft eén op de vijf in de mijnen gewerkt. Met andere woorden, in de mijnen werken en maagkanker lijken niets met elkaar uitstaande te hebben.

Als er meer anderzoek op deze wijze plaatswindt, zullen twee dingen gebeuren. Ten eerste zullen allerlei bestaande vooroordelen worden ontzenuwd. En ten tweede zullen er nieuwe ideeën ontstaan over de oorzaken van allerlei ziektes. Op het gebied van kanker en hart-en vaatziektes is het onderzoek inmiddels in een vrij vergevorderd stadium. Onze kennis van oorzaken van deze ziektes is al redelijk groot. Soms ontstaan er ook discussies, bijvoorbeeld omdat verschillende studies een andere uitkomst geven, of omdat we nog niet de middelen hebben om bepaalde oorzaken goed te meten. Daarbij kleven er soms grote nadelen aan bepaalde onderzoeksontwerpen. Maar problemen zijn er om op te lossen. Hopelijk zal door de vele inspanningen een heel redelijk beeld ontstaan van oorzaken van allerlei kankergezwellen en hart- en vaatzlektes, waarbij de rol van risicofactoren en van beschermende factoren ook gekwantificeerd wordt. Belangrijk lijkt 
mij dat tegelijkertijd alles in het werk wordt gesteld om de vele foute beweringen recht te zetten.

In Nederland en in het buitenland zijn al zoveel collega's doende de etiologie van kanker en hart-envaatziektes te bestuderen dat niemand meer op een Maastrichtse bijdrage zit te wachten. Of het zou om een bijzonder originele vraagstelling moeten gaan, met een mooie onderzoeksopzet. Dat betekent niet dat de capaciteitsgroep Epidemiologie het etiologische pad verlaten heeft. Gelukkig zijn er nog een heleboel andere ziektes die het bestuderen meer dan waard zijn. Ik heb het dan over ziektes die in de sterftetabellen van het Centraal Bureau voor de Statistiek nauwelijks vóorkomen. De meeste ziektes zijn niet fataal, maar wel erg hinderlijk. Daarbij vormen ze een grote bellasting voor de gezondheidszorg. Het valt op dat ook nu allerlei claims over oorzaken op tafel worden gelegd. En dat terwijl goed etiologisch epidemiologisch onderzoek nagenoeg of geheel ontbreekt. Alleen al het toetsen van de vele beweringen kan ons werk verschaffen tot na de eeuwwisseling.

Het is mij een genoegen dat de verschillende medewerkers van de capaciteitsgroep Epidemiologie mij de eer gunnen om een enkel ciffer wit hun onderzoek te presenteren. I k ga U drie voorbeelden geven van etiologische epidemiologie in de contramine.

Voorbeeld 1. Spataderen komen veel voor en dat komt mede doordat we zoveel staan. Er wordt beweerd dat er dus meer gelopen moet worden. Zitten zou ook uit den boze zijn. Piet Leffers in onze capaciteitsgroep ging dat voor U na. Nauwgezet werden de benen onderzocht van zo'n 200 oudere mannen die al jarenlang zittend werk hadden. Ruim de helft $(57 \%)$ bleek tekenen van spataderen te hebben. Maar blijft U rustig zitten. Spataderen komen ook voor bij oudere mannen die veel lopen. Zelfs nog meer dan bij de zittenblijvers. In een groep oudere mannen die op het werk veel moest Iopen, werden volgens dezelfde criteria spataderen aangetroffen bij drie op de vier. Deze uitkomst van het onderzoek kan ook nog op een andere manier gepresenteerd worden. Honderd oudere mannen die veel zitten, zijn - inclusief de mannen zonder spataderen - goed voor 14 meter spatader. Dat is veel "maar in eenzelfde groep die veel loopt, gaat het om niet minder dan 34 meter. Wie liever geen spataderen heeft, kan dus maar beter een zittend leven leiden.

Voorbeeld 2. leder Jaar worden in Nederland ongeveer 18.000 mensen geopereerd aan hun galstenen. In de leerboeken, zeker de wat oudere leerboeken, staat dat galsteenpatiënten een aantal kenmerken bezitten. Ik stap nu even over op het Engels, omdat dan alle woorden met de letter $F$ beginnen: fat, forty, female, fertile, fair. Dikke vrouwen dus van ongeveer 40 
jaar en gezegend met een aantal kinderen. Bovendien zouden ze "fair" zijn. Daarmee word" niet bedoeld dat ze goudeerlijk zijn, maar misschien wel dat ze valak een blonde haarkleur zouden hebben. Karel Thijs in onze etiologische fractie wilde dat eerst nog wel eens zien. Van 200 galsteenpatiënten in ziekenhuis St. Annadal te Maastricht legde hij zo goed mogelijk de originele haarkleur vast. Dat valt soms niet mee, onder andere omdat het verschil tussen lichtblond, donkerblond, bruin en zwart klein kan zijn. Niettemin werd meer dan de helft licht-dan wel donkerblond bevonden, om precies te zijn $59 \%$. Is dus blond haar kenmerkend voor galsteenpatiënten? Dan zou dit in de bevolking van Maastricht, dus bij mensen zonder galstenen, veel minder moeten vóórkomen. Maar helaas, daar was geen sprake van. In de bevolking hadden meer mensen blond haar, namelijk $66 \%$. Galsteen patiënten lijken dus minder vaak blond te zijn. De kans op galstenen is bij blonde mensen niet groter, maar een kwart kleiner. Dat blijkt op te gaan voor mannen en wrouwen, en voor personen met licht- en donkerblond haar. De moraal: de in leerboeken vermelde "klinische blik" kan gezichtsbedrog zijn.

Voorbeeld 3. Rond deze tijd verschijnen in de pers altijd alarmerende berichten over de skiërs, hun ongevallen en hun drankgebruik. De "après ski" zou steeds meer uit de hand lopen en worden gecompleteerd met wrolijkheid vooraf en tussendoor. Ja, en daar komen natuurlijk brokken van. In onze club zit Lex Bouter en hij zocht het samen met de ANWB voor U uit. Aan bijna 200 skiërs die een bot gebroken hadden en 500 skiërs zonder letsel werd de vraag voorgelegd, of ze tijdens de skivacantie well of geen alcohol gebruikten. Van de skiërs met een botbreuk bekende meer dan $2 / 3$ zich daaraan bezondigd te hebben. Slechts $31 \%$ dronk geen alcohol. Datzou dus ongetwijfeld in de groep skiërs zonder letsel heel anders uitpakken en dat was ook zo. Maar wat bleek? In de controlegroep was het percentage drinkers nog veel groter. Hier bleek slechts $22 \%$ geen alcohol te gebruiken. Ervan uitgaande dat op de vragen eerlijk is geantwoord - en daar zijn aanwijzingen voor - zouden skiërs die niet drinken meer kans hebben op een botbreuk. Vergeleken met skiërs die minstens vijf glazen per dag drinken, lijkt die kans 2 a 3 keer $z 0$ groot te zijn. Dat is ook voor ons een verrassende uitkomst, en we houden ons aanbevolen voor een plausibele verklaring. Misschien moet het onderzoek in een andere vorm nog maar eens worden overgedaan.

Ukunt zich met deze voorbeelden voorstellen, hoe sceptisch wij langzamerhand staan tegenover zo ongeveer alles wat over oorzaken van ziektes beweerd wordt. Als de beweringen te stellig worden, nemen wij stelling en gaan in de contramine. Naarmate luider verkondigd word dat dit goed is en dat slecht, roepen wij eerder dat dat nog te bezien staat. Vaak wordt er trouwens niet eens bij verteld, waarvóór iets goed of slecht wordt gevonden voor de alvleesklier? voor de nieren? voor de blindedarm? We nodigen 
iedereen uit om met ons naar de bewijslast van alleriei beweringen te kijken. En wie het vervolgens nodig vindt om een epidemiologisch onderzoek te doen, kan op onze steun rekenen.

Intussen is het natuurlijk niet de bedoeling dat de hoeveelheid weinig gefundeerde gezondheidsadviezen nog verder wordt uitgebreid. Als daarnaar gevraagd wordt, kan misschien af en toe een gericht preventief advies verstrekt worden. Ongevraagd drukwerk met hele en halve voorlichting over zogenaamde "riskante gewoontes" vind ik in zijn algemeenheld discutabel. En het opvoeden van gezonde volwassenen is al helemaal mijn stijl niet. Het voorgestelde "ontmoedigingsbeleid" van de overheld kan mijn goedkeuring dus niet wegdragen. I vind dat de overheid zich minder behoort te richten op eventuele risico's die mensen vrijwillig nemen zonder hun omgeving daarmee lastig te vallen. Laat de overheid zich vooral concentreren op maatregelen ter bestrijding van risico's of ongemakken, waaraam mensen zich maar moeilijk kunnen onttrekken: arbeids-en milieu-omstandigheden dus.

Aan het slot van dit hoofdstuk over etiologische epidemiologie wil ik ook voor de arbeids-en milieuhygiëne wijzen op de vele ongenuanceerde beweringen. Te gemakkelijk wordt soms vergeten dat de dosis het vergif maakt. Als bepaalde verontreiniging ziekmakend is bij een hoge expositie, wil dat nog niet zeggen dat een veel lagere expositie óók een reëel ziekterisico inhoudt. Zonder enige twiffel zijn er - ook in Nederland - periodes van zodanige luchtverontreiniging geweest dat mensen er een longziekte van kregen. Maar bij de nu gangbare concentraties van verontreinigende stoffen in de buitenlucht kan een verband met bronchitis of astma niet worden aangetoond. Het lawaai in veel bedrijven is nog steeds zodanig dat mensen solliciteren naar een vermindering van hun gehoor. Tegelijkertijd is er geen reden om aan te nemen dat het wonen aan een drukke straat óók het gehoor kan aantasten.

In epidemiologisch onderzoek gaat het niet alleen om het wel of niet bestaan van een verband tussen een rísicofactor en een ziekte. Dat verband dient ook te worden gekwantificeerd. Bij hoeveel expositie treedt hoeveel ziekte op en bij wie? Tegen deze achtergrond is het heel nuttig om een aantal beweringen, bijvoorbeeld vanuit het onderzoek in het laboratorium, op hun zogenaamde "dosis-respons relatie" te toetsen. Over de epidemiologie in de bedrijfsgezondheidszorg is in Nederland zelfs een apart boek verschenen. Het heet "Naar een gezonde werkomgeving" en twee mensen van onze capaciteitsgroep, te weten Martien van Dongen en Ferd Sturmans, hebben er een belangrijk aandeel in gehad. 
Het is een bijzonder goede zet van de Rijksuniversiteit Limburg geweest om een aparte capaciteitsgroep Arbeidsgeneeskunde op te richten. Daarmee krijgt het onderzoek op dit gebied - ook het epidemiologische onderzoek -extra aandacht.

Overigens ben ik van mening dat veel problemen in onze arbeids- en milieuhygiëne minder te maken hebben met het ontstaan van allerlei ernstige zlektes, en veel meer met aantoonbare overlast. Laat het zo zijn dat bij de huidige buitenluchtverontreiniging een verband met bronchitis of astma niet kan worden aangetoond. Maar hinder is er wel op diverse plaatsen. Hetzelfde geldt voor bijvoorbeeld het lawaai. Allerlei omgevingslawaai is net niet hoog genoeg om ziekte te veroorzaken, maar er kan wel sprake zijn van een gigantische inbreuk op de privacy. Ook vanuit het idee van overlast is er voor de overheid nog veel werk aan de winkel. 


\section{DIAGNOSTIEK}

In het begin van deze voordracht is de epidemiologie naar de inhoud ingedeeld in beschrijvende, etiologische, diagnostische en prognostische epidemiologie. Over de kennis louter van het vóórkomen van ziektes is weinig gesproken, maar over de etiologische epidemiologie des te meer. Ik hoop met een aantal voorbeelden aannemelijk gemaakt te hebben dat veel beweringen over oorzaken van ziektes best nog eens bekeken mogen worden in epidemiologisch onderzoek.

Daarmee is de koek nog niet op. Er bestaat ook nog klinische epidemiologie en ik voorspel deze richting van de epidemiologie een grote toekomst. Dat geldt zowel voor de diagnostische als voor de prognostische epidemiologie.

De bemoeienis van epidemiologen met de diagnostiek is niet van vandaag of gisteren. Met name de vroegdiagnostiek heeft tot dusver veel aandacht gekregen. Ik heb het dan over screening. We worden gescreend van de wieg tot het graf. Het beoordelen van het nut hiervan is uitermate ingewikkeld. Om die reden wil ik liever niet tot de voorstanders, maar ook niet tot de tegenstanders van screening gerekend worden. Ik voel me voor de meeste vormen van screening het comfortabelste in de middenpositie. Niettemin wil ik hier wél wijzen op een interessant fenomeen. Het idee van screening is in Nederland gepropageerd vanuit de sociale geneeskunde. Vanuit diezelfde sociale geneeskunde heeft zich de epidemiologie ontwikkeld. En in die ontwikkeling is men steeds meer in de contramine gegaan tegenover de voorstanders van screening. De sociaal-geneeskundigen van vroeger noemen zich nu epidemiologen en bestrijden de vraag naar screening die ze zelf mee hebben hel pen creëren. Er is niets op tegen mét de uitkomsten van epidemiologisch onderzoek van mening te veranderen. Maar een interessant fenomeen blijft het wel dat een discipline een deel van zijn eigen kaartenhuis laat instorten, mede op basis van wetenschappelijk onderzoek. Misschien zou dat in andere disciplines óók meer moeten gebeuren.

Bij screening gaat het om een initiatief vanuit de gezondheidszorg. In de dagelijkse praktijk wan de curatieve geneeskunde gaat het initiatief van de patiënt uit. Die komt met een bepaald probleem bij bijwoorbeeld de huisarts en vraagt om hulp. Goede diagnostiek is daarbij een zinvolle tussenstap, maar het gaat om de prognose en eventuele verbetering hiervan door bepaalde adviezen en therapie. Hoe triviaal dat ook lijkt, diagnostiek behoort geen doel op zichzelf te zijn. 
Uil gesprekken met behandelende artsen en ook de nog schaarse literatuur krijg ik de indruk dat onze patiëntenzorg bedreigd wordt door overdiagnostiek. De huisarts lijkt zijn patiënt meer dan vroeger naar een diagnostisch centrum te verwijzen. Als al bijna zeker is dat een bepaalde patiënt de verdachte ziekte niet of wel heeft, is nóg weer nadere diagnostiek zelden verhelderend en soms zelfs verwarrend. De ziekenhuizen lijken de laatste jaren steeds meer te worden opgesierd met allerlei geavanceerde, vaak peperdure apparaten en ik vraag me af, of misschien alleen de industrie daar beter van wordt. Er zijn natuurlijk evidente uitzonderingen op de regel, maar het toegevoegde nut van veel nieuwe diagnostiek is nog niet aangetoond.

Ik vrees bovendien een gevaarlijke bijwerking. Met de toenemende hang naar specialistische diagnostiek dreigt de belangstelling te verflauwen voor het uitdiepen van de klachten van de patiënt, de zogenaamde gerichte anamnese. Ook bestaat het gevaar dat het vakmanschap van goed lichamelijk onderzoek verloren gaat. Men begint meer te vertrouwen op de waarneming van een apparaat dan op de eigen waarneming. En de anamnese zou "subjectief" zijn en "niet exact genoeg", dus die krijgt misschien nog minder aandacht. Vanuit de diagnostische epidemiologie willen we graag bijdragen om de betekenis van bepaalde klachten en symptomen opnieuw te bezien. $\mathbb{k}$ had $U$ beloofd in de contramine te zijn. Ons uitgangspunt bij dergelijk onderzoek is dus dat een gerichte anamnese en een gericht lichamelijk onderzoek wel eens veel belangrijker voor de diagnostiek kunnen zijn dan alle nadere diagnostiek samen.

Intussen wordt er in de leerboeken wel het een en ander beweerd over het zogenaamde "klinisch beeld" van diverse aandoeningen. Daarbij is vaak niet duidelijk, waarop die beweringen gebaseerd zijn. Bij de bespreking van de etiologische epidemiologie betoogde ik dat veel ideeën over oorzaken van ziektes enkel berusten op autoritaire mededelingen "eventueel aangevuld met een mechanistische verklaring. Dat lijkt hier ook het geval te zijn. Erzijn maar weinig studies, waarin geprobeerd is de relatie tussen klachten en symptomen enerzijds en de aan-of afwezigheid van een bepaalde ziekte anderzijds in kwantitatieve zin te schatten. Daar komt bij dat publicaties uit de specialistische geneeskunde een vertekend beeld kunnen geven vanwege allerlei selectiefenomenen.

Daarom kan het diagnostisch epidemiologische onderzoek beter gestart worden in de algemene bevolking of op het niveau van de huisarts. Een extra reden hiervoor is dat men daar vanzelf meer is aangewezen op de anamnese en het lichamelijke onderzoek, bij ontbreken van geavanceerde diagnostische apparatuur. Dat laatste houdt tevens in dat in het wetenschappelijke onderzoek de kliniek vaak óók een rol kan spelen, namelijk bij het zo 
definitief mogelijk vaststellen van de ziekte, de zogenaamde "gouden standaard".

Het wordt hoog tijd om met voorbeelden te illustreren, hoe leuk en belangrijk dergelijk onderzoek is. Een aantal studlies die vanuit onze capaciteitsgroep in samenwerking met andere disciplines verricht worden, zijn nog in de fase van dataverzameling. Daarom volsta ik aan het eind van dit hoofdstuk met slechts twee voorbeelden van diagnostische epidemiologie in de contramine.

Voorbeeld 1 . Is er een reden om bij patiënten met hoofdpijn eerder aan hoge bloeddruk te denken? Omdat dat in een aantal leerboeken beweerd wordt, wilden wij dat graag in epidemiologisch onderzoek bevestigen en kwantificeren. Uit een bevolkingsonderzoek bij mannen en vrouwen van middelbare leeftijd haalden we 200 personen die iedere week middelen tegen hoofdpijn gebruikten. Van dezen bleek bij meting $14 \%$ hoge bloeddruk te hebben volgens de gangbare criteria. Uiteraard werd de bloeddruk ook gemeten bij een grote groep personen die deze middelen zelden of nooit gebruikte. Hiervan had $13 \%$ hoge bloeddruk - nagenoeg evenveel dus. Op basis van dit en ander epidemiologisch onderzoek mag worden verondersteld dat hoofdpijn niet of nauwelijks een indicatie geeft voor de aanwezigheid van hoge bloeddruk.

Voorbeeld 2. Wie weet niet dat je bij onverklaarde moeheid de diagnose "bloedarmoede" moet overwegen? André Knottnerus in onze diagnostische unit vond dat er nog wel een epidemiologisch onderzoek bij kon. Samen met negen huisartsen uit Heerlen en het Haematologisch Laboratorium van het De Wever Ziekenhuis werden gegevens verzameld van ongeveer 150 patiënten mét en 150 patiënten zonder onverklaarde moeheid. Steeds ging het om volwassen mannen en vrouwen die het spreekuur van de huisarts bezochten. Bij ledereen werd het hemoglobine gemeten in zogenaamde millimolen per liter bloed. De hoogte van het hemoglobine zegt iets over de mate van bloedarmoede dan wel bloedrijkdom. Gemiddeld was dit in de groep patiënten zonder moeheid bij de mannen bijna 10 en bij de vrouwen bijna 9 . En nou komt het: in de groep patiënten met onverklaarde moeheid was dit precies even hoog. Ook kwamen daar net zoveel hogere en lagere waarden voor. Met andere woorden, onverklaarde moeheid op het spreekuur van de huisarts zegt niet zoveel over de aanwezigheid van bloedarmoede. Bij alle onderzochte personen bleek trouwens een laag hemoglo. bine, onder de 7, geen enkele keer voor te komen. Bloedarmoede is kennelijk een zeldzame ziekte. En dat hadden zelfs wij met onze contramine niet gedacht. 


\section{PROGNOSE}

Zoals ik eerder aankondigde, gaat het in de klinische epidemlologie niet alleen om de waarde van bepaalde diagnostiek en het herwaarderen van klachten en symptomen. Uiteindelijk heeft alle diagnostiek maar een hoofddoel: Inschatten van de prognose en hoe die eventueel in gunstige zin beinvloed kan worden. Bij de diagnostiek speelt kennis van risicofactoren meestal een beperkte rol. Algemeen wordt aangenomen dat deze factoren vaak van grote betekenis zijn bij het inschatten van de prognose. Risicofactoren en prognostische factoren zouden twee broertjes zijn of zelfs een eeneiige tweeling.

Die gedachte ligt erg voor de hand en ik zal ze illustreren met een praktijkvoorbeeld. Enkele jaren geleden verscheen in het tijdschrift van de Nederlandse Hartstichting een artikel over de schadelijke werking van alcohol op het hart. Ik reageerde met een overzichtsartikel van de literatuur over de beschermende rol van matig alcoholgebruik bij het ontstaan van een hartinfarct. In de pers werd daar nogal wat aandacht aan besteed. En toen gebeurde lets heel leerzaams. Ik kreeg zeer veel reacties van mensen die al een hartzlekte hadden. Steeds opnieuw werd mijn mening gevraagd over het volgende. Als alcoholgebruik kan bijdragen om bij gezonde mensen een hartinfarct te voorkomen, heeft het dan ook een gunstige werking op de prognose van angina pectoris ("pijn op de borst" bij inspanning, een voorstadium van het hartinfarct)? En hoe staat het met de kans op een nieuw hartinfarct bij mensen die een eerste infarct overleefd hebben? In hoeverre wordt die kans in positieve zin beinvloed door alcoholgebruik? Ik kreeg oprecht de indruk dat men bovendien mijn eventuele adviezen zonder reserve wilde opvolgen. Had ik gezegd dat vooral eau de cologne mij well wat leek, dan had men het met liters gekocht en opgedronken. Maar dat zel ik niet, want ik had daar geen idee van. Er is wel veel epidemiologisch onderzoek verricht naar de rol van alcohol bij het ontstaan van het hartinfarct (als surrogaat voor de incidentie werd soms de sterfte genomen). maar aparte aandacht voor de invloed op de prognose is er niet of nauwelijks geweest. Terwijl er net grote vraag was naar de uitkomsten van dergelijk onderzoek.

Met dit voorbeeld hoop ik duidelijk gemaakt te hebben dat er alle reden is om meer aandacht te schenken aan de prognostische epidemiologie. Welke factoren - vooral beïnvloedbare factoren - spelen een rol bij het ziektebeloop, naast de invloed van bepaalde therapieën, en hoe groot is die rol? Mede door epidemiologisch onderzoek is algemeen aanvaard dat het krijgen van ziekte niet lets is dat louter op toeval of pech berust. Het heeft ook te maken men een samenspel van allerlei beschermende en risicofacto- 
ren. Zelfs begint men onderscheid te maken tussen factoren die vooral het allereerste begin van ziekte bepalen en factoren die een rol spelen bij het wel of niet doorzetten van ziekte. In de kennis van oorzaken van kanker zijn de begrippen "initiatoren" en "promotoren" inmiddels geaccepteerd.

Het ligt voor de hand om die lijn door te trekken. In de literatuur wordt nog steeds gesproken van het "natuurlijk" beloop van zlekte. Dat is de situatie dat er niet wordt behandeld en men de ziekte op zijn beloop laat. Ik maak bezwaar tegen het woord "natuurlijk", zoals men ook niet behoort to spreken van thet "natuurlijk" ontstaan van ziekte. In het beloop van zlekte spelen waarschijnlijk allerlei prognostische factoren een gunstige en minder gunstige rol. Bestudering van deze factoren lijkt me een boeiende taak voor epidemiologen.

Het ligt voor de hand om aan risicofactoren ook een prognostische betekenis toe te kennen. Als ziekte als een continuum gezien wordt en niet als een donderslag bij heldere hemel, zullen bepaalde factoren misschien continu een rol spelen. Het is dan bijzonder relevant om die rol in de verschillende stadia van de ziekte te kwantificeren.

Maar er zijn best ook factoren te bedenken die alleen in een bepaald stadium actief zijn. Riekie de Vet in onze capaciteitsgroep vermoedt dat het eten van bepaalde groentes beschermt tegen het krijgen van kanker. Dat zou komen, omdat daarin veel caroteen zit, een soort vitamine. In een groot experiment wordt uitgezocht, of deze stof ervoor kan zorgen dat zogenaamde "dysplasie" (een voorstadium van kanker) niet overgaat in kanker. Het gaat dus om een invloed in de promotiefase. Het onderzoek is nog niet afgesloten, maar stel dat ze gelijk krijgt. Dan betekent dat natuurlijk nog niet dat het eten van groente ook de initiatie van kanker tegengaat. En zeker ook niet dat mensen met al bestaande kanker extra veel groente dienen te eten om eventuele uitzaaiingen tegen te gaan of zelfs te laten verdwijnen.

Zoals het voorstelbaar is dat bepaalde factoren alleen in een bepaald ziektestadium een rol spelen, zo is ook denkbaar dat bepaalde factoren in het ene zlektestadium als risicofactor gekwalificeerd moeten worden en in het andere stadium een beschermende werking hebben. Er zijn bijvoorbeeld aanwijzingen dat veel trimmen de slijtage bevordert van het enkel-en kniegewricht en dus een oorzaak is van zogenaamde arthrose. Tevens komt het me als plausibel voor dat mensen met beginnende arthrose lets aan lichaamsbeweging moeten doen om het proces een halt toe te roepen.

Met het laatste voorbeeld begeef ik me wel op glad ijs. Want of de prognose van arthrose verbetert door lichaamsbeweging, is bij mijn weten nooit uitgezocht. In zijn algemeenheid is er nog zo weinig gestudeerd op de betekenis van prognostische factoren bij allerlei zlektes dat ik versteld sta 
wan de hoeveelheid goed bedoelde adviezen aan patiënten zonder enige fundering - zeker niet in kwantitatieve zin. De curatieve gezondheidszorg lijk" vergeven te zijn van aanbevelingen onder het motto: "Baat het niet, het schaadt ook niet". En dat laatste is natuurlijk niet geheel correct, als men patienten vraagt om zich te on thouden van allerlei plezierige gewoontes. De prognostische epidemiologie staat nog in de kinderschoenen. Vanuit onze jonge capaciteitsgroep hopen we ook deze richting van de epidemiologie verder te kunnen ontwikkelen. Soms zal dat vanuit de contramine gebeuren en we hopen dat andere disciplines daarin met ons mee willen gaan.

Er zijn ideale mogelijkheden om de etiologische, diagnostische en prognostische epidemiologie te integreren. Ik zei al dat bestudeerd kan worden, of veronderstelde etiologische factoren - oorzaken dus van het ontstaan van ziek te - ook een prognostische betekenis hebben. Maar vanuit de gevraagde aandacht voor de diagnostiek zijn er all evenzeer lijnen naar de etiologie en naar de prognose. Zoals eerder genoemd, is een gangbare vorm van etiologisch epidemiologisch onderzoek het zogenaamde patiënt-controle onderzoek. Daarin wordt uitgegaan van een groep patiënten met een bepaalde ziekte, liefst in een zo vroeg mogelijk stadium van ontdekking. Hierin wordt het vóórkomen van een veronderstelde oorzaak gemeten. Hetzelfde doet men in een geschikte controlegroep van personen die de betreffende ziekte niet hebben. Het loont nu zeer de moeite om in beide groepen ook klachten en symptomen te meten die verondersteld worden met de ziekte samen te hangen. Aldus kan in een moeite mee het onderscheidend vermogen hiervan bestudeerd worden. Daarna gaan we het beloop bekijken in de groep patiënten, de controlegroep doet niet meer mee. In deze groep patiënten, allen in het beginstadium van de ziekte, zal het met sommigen slechter aflopen dan met anderen. Aan de orde is nu de vraag, of de eerder gemeten etiologische factor ook een prognostische betekenis heeft. De klachten en symptomen hebt U inmiddels al vastgelegd en soms is een evaluatie thiervan bruikbaar als een van de uitkomstmaten. Het prognostische deel van het epidemiologische onderzoek kan trouwens heel mool als een gecontroleerd interventie-onderzoek worden opgezet. En voor wie dat wil, kan er nog weer een nieuw patiënt-controle onderzoek op volgen.

Wellicht is de pointe van de laatste opmerkingen $U$ enigszins ontgaan. Ze zijn vooral bedoeld voor de epidemiologen onder het gehoor. Zij hadden wellicht ook minder willen horen over de inhoud van mijn vak, en meer over de methodiek. Epidemiologie wil aan de ene kant bijdragen aan de kennis van allerlei ziektes, maar aan de andere kant is er bijzonder veel interesse in de onderzoeksmethodiek. Mijn collega's weten, hoe ik in vuur kan raken over de keuze van een juiste controlegroep, ter vermijding van allerlei vertekening in de onderzoeksresultaten. Ik weet maar al te goed dat allerlei 
ongeoorloofde beweringen ook op basis van epidemiologisch onderzoek gedaan kunnen worden. Dat komt omdat de gekozen methodiek soms niet deugt of omdat onze kennis van de methodiek nog ontoereikend is. Desnoods vanuit de contramine wil ik ook graag een bijdrage leveren aan het werbeteren van onze eigen onderzoeksontwerpen.

Intussen hoop ik dat $U$ wel een beeld hebt gekregen van wat bij ons groeit en bloeit, en altijd weer boeit. Epidemiologen zijn geen mensen die de helle dag gebogen zitten over publicaties van het Centraal Bureau voor de Statistiek. Ook zijn wij niet de statistici van de Faculteit der Geneeskunde, laat staan degenen die de hele dag achter de computer zitten. En hoewell de nieuwe "Van Dale" dat nog aangeeft, is epidemiologie al lang niet meer de leer van de epidemieën van besmettelijke ziektes. Onze belangstelling strektzich uit over veel meer ziektes en daarvan heb ik Ueen aantal voorbeelden gegeven. Ook gaat het niet primair om het voorkómen van ziektes, maar om het vóórkomen van ziektes. Het meten van dit vóórkomen bij groepen mensen wordt voor ons pas echt interessant, als daarmee inzichten verkregen worden in de etiologie, diagnostiek en prognose. 


\section{EPILOOG}

Bij een inaugurele rede hoort ook een epiloog: een slotwoord dat op het woord "epidemioloog" lijkt, met dat werschil dat het iets gemakkelijker is uit te spreken. Dit is het moment om een aantal mensen te bedanken. Zonder hen zou ik het nooit zover gebracht hebben.

Allereerst mijn ouders. Als mijn moeder nog geleefd had; zou ze genoten hebben van een bijeenkomst als deze. Mijn vader is hier wel en hem wil ik vooral bedanken vanwege miln "contraministische" opvoeding. Van mijn vrouw heb ik proberen te leren dat het goed is om niet altijd in de contramine te zijn. Maar mijn dochter Eva heeft het ook. Nooit eens iets zo maar aannemen en altijd willen weten, waarop een bewering gebaseerd is. I $k$ denk dat het, zo niet erfelijk, dan toch wel familiair is.

Na mijn medische studie kreeg ik direct een baan bij het Coronel Laboratorium van de Universiteit van Amsterdam. De stemming om onderzoek in het veld te doen, zat er gelijk in. Ik weet nog, hoe ik de mensen daar heb proberen te overtuigen dat de naam Coronel Laboratorium moest worden veranderd in Coronel Instituut. Want medische milleukunde en arbeidshygiëne, daarvoor moet je niet in het laboratorium zijn. Het is me niet gelukt om de naam te veranderen en dat is misschien maar goed ook. In die tijd heb ik well hél veel geleerd over de mogelijkheden en beperkingen van mijn vak. Mijn promotor Zielhuis is voor mij nog steeds het klassieke type professor, waar we zuinig op moeten zijn. Soms benauwt het idee me dat ik met mijn benoeming in staat wordt geacht om op zijn niveau te werken. Ook de andere mensen van het Coronel Laboratorium wil ik bedanken, in het bijzonder alle mensen van de lawaaigroep en natuurlijk het gouden duo Sallé-Verberk. Met hen heb ik geleerd, hoe leuk epidemiologie wel niet is.

In 1980 begon ik in Maastricht bij wat toen nog de capaciteitsgroep Gezondheidszorgonderzoek heette. En al weer had ik het geluk tegen een gouden duo aan te lopen: van Arkel-Sikkens. Zij hebben me geleerd dat het onderwijs aan de Rijksuniversiteit Limburg bijzondere kwaliteiten heeft. Etiologische epidemiologie vonden ze best aardig, maar $\mathrm{GZO}$, daar ging het om. Voor zover daarmee hetzelfde bedoeld wordt als klinische epidemiologie, wil ik hum pionlerswerk graag voortzetten. Helaas zijn ze inmididels naar elders vertrokken en gelukkig zijn er intussen weer zoveel nieuwe, capabele en sociabele medewerkers bijgekomen. ledereen van de capaciteitsgroep Epidemlologie en ook van de sector Gezondheidszorgvoorzieningen wil ik bedanken voor het vertrouwen dat in mij gesteld wordt. Jullie steun in de periode vóor mijn benoeming zal ik niet snel vergeten. Die steun, alsmede 
de steun van een aantal collega's in het land, was voor mili nog belangrijker dan het moment van de voordracht of het moment dat het Hare Majesteit behaagde om mij te benoemen.

Mijnheer de rector, geachte leden wan de universitaire gemeenschap, ik glunder bij de gedachte dat $U$ mij hebt aangewezen als degene die naast Sturmans de epidemiologische kar mag trekken. Dat ik "eigen kweek" ben, geeft aan deze bijeenkomst een bijzondere betekenis. Ik zal alles in het werk stellen om aan Uw verwachtingen te voldoen. Sterker nog, ik geef U op een briefje dat $U$ nog veel profijt zult trekken van de capaciteit die wij in onze epidemiologie-groep hebben.

Beste wrienden, dit is een plechtige gebeurtenis. Er is zelfs een protocol en tot besluit ga ik daaruit voorlezen. I $\mathrm{k}$ zal me beperken tot artikel IX dat handelt over de receptie. Deze vindt plaats in de ruimte hiernaast. En nu citeer ik: "Er is geen receptie met rijvorming. De gasten begeven zich naar de receptieruimte en feliciteren de orator, wanneer de gelegenheid daartoe zich voordoet". Ik bedank U woor Uw aanwezigheid hier en hoop U tevens te ontmoeten tijdens het nu volgende, minder officiële deel van deze gebeurteniis.

En hiermee aanvaard ik het ambt van gewoon hoogleraar in de epidemiologie aan de Rijksuniversiteit Limburg. 